\title{
Radiation Protection Clothing in X-Ray Diagnostics - Influence of the Different Methods of Measurement on the Lead Equivalent and the Required Mass
}

\section{Strahlenschutzkleidung in der Röntgendiagnostik - Einfluss der Messmethoden auf den Bleigleichwert und die erforderliche Masse}

Authors

Affiliation
T. Schöpf, T. Pichler

Institut for Radiation Protection and Dosimetry, LKH Innsbruck, Austria
Key words

- shielding weight

- attenuation

- radiation shielding clothing

received $\quad 1.12 .2015$

accepted $\quad 2.4 .2016$

Bibliography

DOI http://dx.doi.org/

10.1055/s-0042-106651

Published online: 1.6.2016

Fortschr Röntgenstr 2016; 188:

768-775 @ Georg Thieme

Verlag KG Stuttgart · New York . ISSN 1438-9029

Correspondence

Dr. Thomas Schöpf

Institut for Radiation Protection and Dosimetry, LKH Innsbruck

Innrain 66

6020 Innsbruck

Austria

Tel.: ++43/512/50425720

Fax: $++43 / 512 / 50425729$

thomas.schoepf@tirol-kliniken.at

\section{Abstract}

$\nabla$

Purpose: The determination of attenuation compared to lead for lead-free and lead-reduced protective clothing depends strongly on the different methods of measurement. The standards EN 61331-1 (2002), DIN 68571 und IEC 61331-1 (2014) are now available for the testing of protective clothing. These standards define methods in the narrow beam and in the inverse broad beam geometry with partially different radiation qualities. In the narrow beam the scattered radiation and fluorescence are not considered due to the arrangement. Therefore, the protective effect of lead-free materials will be incorrectly estimated compared to lead material. The influence of the different methods of measurement on the lead equivalent and the required mass of radiation protection clothing was examined.

Materials and Methods: The lead equivalents for material samples for commercially available protective clothing were determined. These samples were made of lead and leadreduced and lead-free materials. For determination of the attenuation equivalents, certified lead foils with high purity and a precise thickness of 0.05 to $1.25 \mathrm{~mm}$ were used.

Results: The measurements indicate that the lead equivalent depends on the method of measurement and the radiation quality. For $\mathrm{X}$-ray tube voltages below $110 \mathrm{kV}$, lead-free or lead-reduced materials show a higher lead equivalent compared to lead material in some cases. Significant mass reductions of more than $10 \%$ compared to lead material are only achievable with a limited range of use up to $100 \mathrm{kV}$.

Conclusion: The implementation of an internationally accepted measuring standard for radiation protection clothing is reasonable and necessary. If standard IEC 61331-1 (2014) can fill this role is unknown.

Key points

- The attenuation factor and the lead equivalent depend strongly on the method of measurement.

- The used X-ray spectra are only partially comparable with the spectra of scattered radiation.

- Mass reductions for protective clothing are only achievable with a limited range of use.

Citation Format:

- Schöpf T, Pichler T. Radiation Protection Clothing in X-Ray Diagnostics - Influence of the Different Methods of Measurement on the Lead Equivalent and the Required Mass. Fortschr Röntgenstr 2016; 188: 768-775

\section{Zusammenfassung}

Ziel: Bei bleifreier oder bleireduzierter Strahlenschutzkleidung ist die Ermittlung der Schwächungseigenschaften dieser Materialien in Vergleich zu Blei stark von der Messmethode abhängig. Derzeit stehen für die Überprüfung der Abschirmwirkung von Schutzkleidung die Normen EN 61331-1 (2002), DIN 6857-1 und IEC 61331-1 (2014) zur Verfügung. Diese Normen definieren Messmethoden im schmalen Strahlenbündel und in der inversen Breitstrahlgeometrie mit teilweise unterschiedlichen Strahlenqualitäten. Im schmalen Strahlenbündel werden durch den Messaufbau Streu- und Fluoreszenzen nicht berücksichtigt. Dies führt bei der Bewertung bleifreier Schutzkleidung im Vergleich zu Bleigummi zu Fehleinschätzungen der Schutzwirkung. Ziel dieser Arbeit ist es, diese Prüfmethoden zu vergleichen und die Auswirkungen auf die notwendigen Massen der Strahlenschutzkleidung zu zeigen. Material und Methode: Die Bleigleichwerte wurden an Materialproben für handelsübliche Schür- 
zen gemessen. Diese Proben bestehen aus bleihaltigen, bleireduzierten oder bleifreien Materialien. Zur Bestimmung der Schwächungsgleichwerte dienten zertifizierte Bleifolien mit hoher Reinheit und genauer Dicke von 0,05-1,25 mm.

Ergebnisse: Die Messungen ergaben, dass die Bleigleichwerte stark von der Messmethode und von der Strahlenqualität abhängen. Bei Röntgenröhrenspannungen unterhalb von $110 \mathrm{kV}$ weisen bleireduzierte und bleifreie Materialien zum Teil sogar höhere Bleigleichwerte als das Material aus Blei auf. Relevante Einsparungen im Gewicht bzw. der Masse von mehr als $10 \%$ einer bleifreien oder bleireduzierten Strahlenschutzschürze im Vergleich zum Material aus Blei lassen sich nur mit einem eingeschränkten Nutzungsbereich bei Röntgenröhrenspannungen bis $100 \mathrm{kV}$ erzielen.

Schlussfolgerung: Für die Hersteller und Anwender von Strahlenschutzkleidung ist die Etablierung eines international anerkannten Prüfstandards für Strahlenschutzkleidung sinnvoll und notwendig. Ob die neue Prüfnorm IEC 61331-1 (2014) sich hier etablieren kann, ist noch ungewiss.

\section{Introduction}

$\nabla$

The introduction of lead-free and lead-reduced radiation protection clothing has made it a matter of importance to determine the attenuation properties of these materials. The lower mass of lead-free and lead-reduced radiation protection clothing is cited as a particular advantage.

The protective value of radiation protection clothing is still based on the equivalent lead thickness. Therefore, the lead attenuation equivalent or the "lead equivalent" is still specified in " $\mathrm{mm} \mathrm{Pb}$ ".

However, the determination of this lead equivalent for leadfree or lead-reduced materials is dependent on the method of measurement. In the case of lead-free and lead-reduced radiation protection clothing, the lead equivalent depends on the radiation quality, i.e., on the X-ray tube voltage and the filtration of the X-radiation. In addition, the measuring arrangement has a significant effect on the result.

The measuring arrangement in the narrow beam according to EN 61331-1 (2002) [1] records the radiation passing through the attenuating material without interaction. The scattered radiation and fluorescence produced by the material are not recorded in this measuring arrangement even though they contribute to dose load. Corresponding studies have already been conducted by Eder et al. [2], Schlattl et al. [3] and McCaffrey et al. [4].

Measurements in the broad beam record the forward scattered radiation and fluorescence. However, very large material samples are necessary for this measuring arrangement which makes this method impractical.

Therefore, inverse broad beam geometry was introduced in DIN 6857-1 [5]. The scattered radiation and fluorescence in small material samples can be recorded with this method. Comparisons by Pichler et al. [6] between measurements in the narrow beam according to EN 61331-1 (2002) and in the inverse broad beam geometry yielded very different results for the lead equivalents of lead-free and lead-reduced radiation protection clothing.

The methods listed above were combined into one standard in the new version of IEC 61331-1 (2014) [7]. This new standard describes the procedure for measurements in the narrow and the broad beam and in the inverse broad beam geometry.

However, several changes were made in IEC 61331-1 (2014). In particular, the filtration of X-radiation was significantly reduced in IEC 61331-1 (2014) compared to EN 61331-1 (2002) and DIN 6857-1. One standard filtration of $2.5 \mathrm{~mm} \mathrm{Al}$ is used for all X-ray tube voltages in IEC 61331-1 (2014).

The goal of this study is to compare the above test methods and to show the effects on the required masses of radiation protection clothing.

\section{Materials and Methods \\ $\nabla$}

The attenuation measurements were performed using the following methods:

- EN 61331-1 (2002) in the narrow beam with copper filtration, called $\mathrm{Cu}$ narrow ( $\bullet$ Fig. 1 )

D DIN 6857-1 in inverse broad beam geometry with copper filtration ( $\bullet$ Fig. 2 ), referred to as $\mathrm{Cu}$ inverse

- IEC 61331-1 (2014) in the narrow beam with aluminum filtration, called Al narrow ( $\bullet$ Fig. 1)

- IEC 61331-1 (2014) in the inverse broad beam geometry with aluminum filtration, called $\mathrm{Al}$ inverse ( $\bullet$ Fig. 2 )

10 different currently available materials for radiation protection clothing were tested. The test samples consisted of lead (material 1), lead-reduced materials (materials 2 and 10), and lead-free materials (numbers 3, 4, 5, 6, 7, 8, and 9). The nominal lead equivalents are $0.25 \mathrm{~mm} \mathrm{~Pb}, 0.35 \mathrm{~mm} \mathrm{~Pb}$, and $0.5 \mathrm{~mm} \mathrm{~Pb}$. The material numbers used here correspond to the numbers used in 0 Fig. 4, 5 and in 0 Table 3-6.

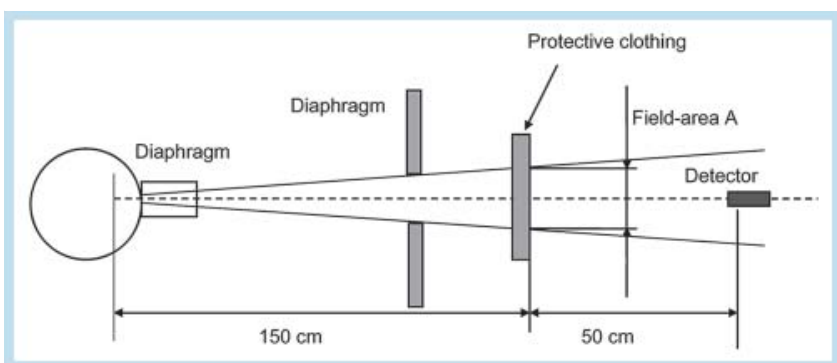

Fig. 1 Measuring arrangement in the narrow beam according to EN 61331-1 (2002) and IEC 61331-1 (2014).

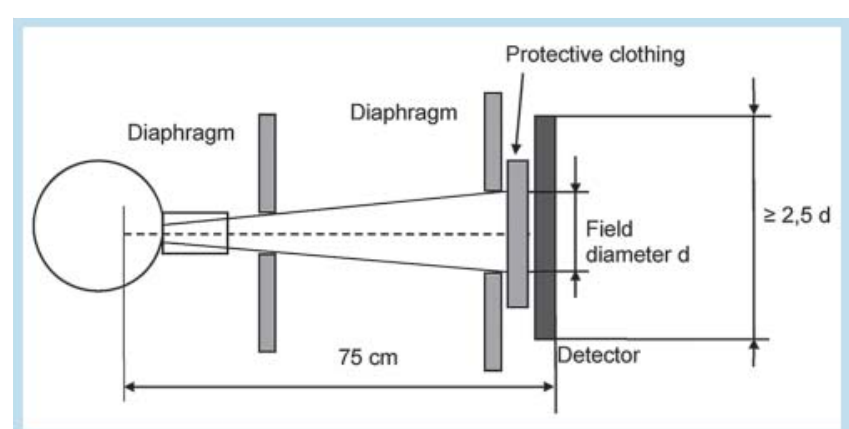

Fig. 2 Measuring arrangement in the inverse broad beam geometry according to DIN 6857-1 and IEC 61331-1 (2014). 


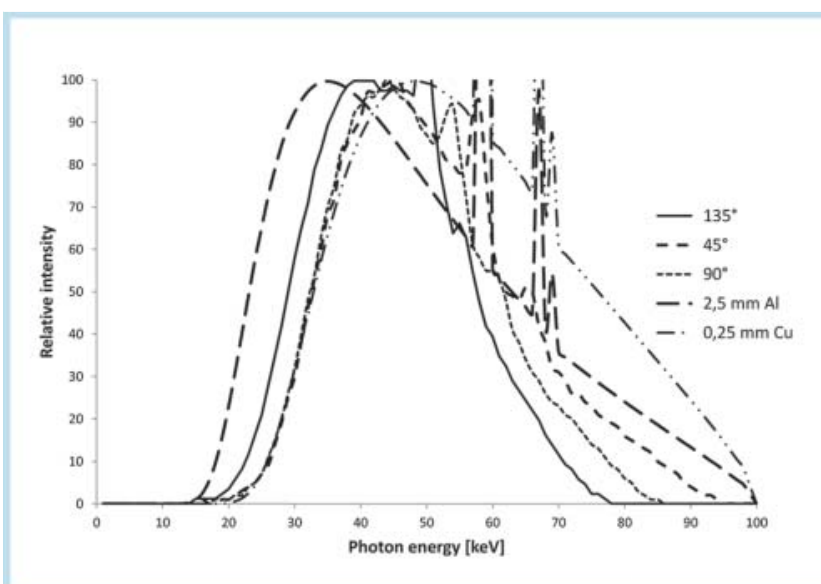

Fig. 3 Backscattered X-ray spectra for a scattering angle of $135^{\circ}$ due to the incident direction of the $X$-ray beam of the phantom and for a scattering angle of $90^{\circ}$ (perpendicular of the incident beam) and $45^{\circ}$ (lateral forward scattering through the phantom) from Fehrenbacher et al. [9] compared to two X-ray spectra with filtration of $2.5 \mathrm{~mm} \mathrm{Al}$ and $0.25 \mathrm{~mm} \mathrm{Cu}$.

Table 1 Radiation qualities used for the measurements according to EN 61331-1 (2002) and DIN 6857-1 (tube voltages, total filtrations and mean energies).

\begin{tabular}{|c|c|c|}
\hline $\begin{array}{l}\text { tube voltage } \\
{[\mathrm{kV}]}\end{array}$ & $\begin{array}{l}\text { total filtration } \\
\text { [mm Cu] }\end{array}$ & $\begin{array}{l}\text { mean photon energy } \\
\text { [keV] }\end{array}$ \\
\hline 40 & 0.05 & 26.0 \\
\hline 50 & 0.08 & 32.3 \\
\hline 60 & 0.10 & 37.2 \\
\hline 80 & 0.15 & 46.8 \\
\hline 100 & 0.25 & 57.0 \\
\hline 120 & 0.40 & 66.4 \\
\hline 150 & 0.70 & 79.2 \\
\hline
\end{tabular}

Table 2 Radiation qualities used for the measurements according to IEC 61331-1 (2014) (tube voltages, total filtrations and mean energies).

\begin{tabular}{|c|c|c|}
\hline $\begin{array}{l}\text { tube voltage } \\
{[\mathrm{kV}]}\end{array}$ & $\begin{array}{l}\text { total filtration } \\
\text { [mm Al] }\end{array}$ & $\begin{array}{l}\text { mean photon energy } \\
{[\mathrm{keV}]}\end{array}$ \\
\hline 50 & 2.5 & 32.1 \\
\hline 70 & 2.5 & 38.8 \\
\hline 90 & 2.5 & 45.2 \\
\hline 110 & 2.5 & 50.6 \\
\hline 130 & 2.5 & 55.2 \\
\hline 150 & 2.5 & 59.3 \\
\hline
\end{tabular}

Samples were available in all specified nominal lead equivalent values for some materials.

The tests were performed on an X-ray therapy system (Xray generator CP 225 from X-STRAHL, X-ray tube MIR-226 from COMET). The anode angle of the X-ray tube is $30^{\circ}$.

A dosimeter, model UNIDOS by PTW, Freiburg, was used for the dose measurements. A $6 \mathrm{ccm}$ shadow-free flat chamber (type 34069) was used in the narrow beam. For the measurements in inverse broad beam geometry, a $75 \mathrm{ccm}$ shadow-free flat chamber (type 34060) was used. Both chambers have a maximum response dependence on the radiation quality of $2 \%$. The requirements of IEC 61331-1
(2014) and thus also of the other testing standards regarding response are therefore met.

The mass was determined for all samples with an LP 1200SOCE scale from SARORIUS.

The radiation qualities specified in 0 Table 1 were used to determine the attenuation properties according to EN 61331-1 (2002) and DIN 6857-1. In contrast, the required total filtration according to IEC 61331-1 (2014) is $2.5 \mathrm{~mm}$ Al for all X-ray tube voltages ( $\bullet$ Table 2 ).

The corresponding pure copper filter or pure aluminum filter was used to generate the radiation qualities. The inherent filtration of the X-ray tube of $0.8 \mathrm{~mm}$ Be can be ignored here.

The mean photon energies of the X-ray spectra were calculated with the program SpekCalc [8]. Due to the lower filtration of the radiation qualities with aluminum according to IEC 61331-1 (2014), the mean photon energies of these Xray spectra are lower than those in the case of copper filtrations.

Radiation protection clothing should provide adequate protection primarily against scattered radiation from the patient.

- Fig. 3 shows the measured spectra of scattered radiation at $100 \mathrm{kV}$ according to Fehrenbacher et al. [9]. These spectra of scattered radiation were measured using a water phantom with a filtration of $3.0 \mathrm{~mm} \mathrm{Al}$.

In comparison, the X-ray spectra with $2.5 \mathrm{~mm} \mathrm{Al}$ according to EC 61331-1 (2014) and with $0.25 \mathrm{~mm} \mathrm{Cu}$ according to EN 61331-1 (2002) and DIN 6857-1 are shown in 0 Fig. 3. These $\mathrm{X}$-ray spectra were calculated with the program SpekCalc.

All spectra listed in $\bullet$ Fig. 3 were standardized to the maximum intensity of bremsstrahlung. The $\mathrm{K}_{\alpha}$ and $\mathrm{K}_{\beta} \mathrm{X}$-ray fluorescence lines of the $\mathrm{W}$-anode of the spectra calculated with the program SpekCalc and the back-scattered fluorescence peak of the spectrum scattered with $135^{\circ}$ are consequently not fully shown in some cases.

Therefore, the bremsstrahlung spectrum can be better compared with the spectra of scattered radiation determined by Fehrenbacher et al. There are significant differences between the spectra of scattered radiation and the X-ray spectra with respect to both the maximum photon energy and the mean photon energy.

The spectra of scattered radiation show a significant dependence on the scattering angle. The X-ray spectra that were used for the testing of radiation protection materials are therefore only a rough approximation compared to real conditions.

Reference measurements using pure lead foils with a thickness between $0.05 \mathrm{~mm}$ and $1.25 \mathrm{~mm}$ lead were used to determine the attenuation equivalents. These reference measurements can be used to calculate the attenuation equivalent in relation to lead by determining the attenuation factor of a test sample.

Attenuation factor $\mathrm{F}$ is determined by the ratio of measured air kerma values without test sample $K_{0}$ to the air kerma values with test sample $K_{x}$. The thus determined attenuation factors correspond to the attenuation factors of the testing standards.

$\mathrm{F}=\frac{\mathrm{K}_{0}}{\mathrm{~K}_{\mathrm{x}}}$ 


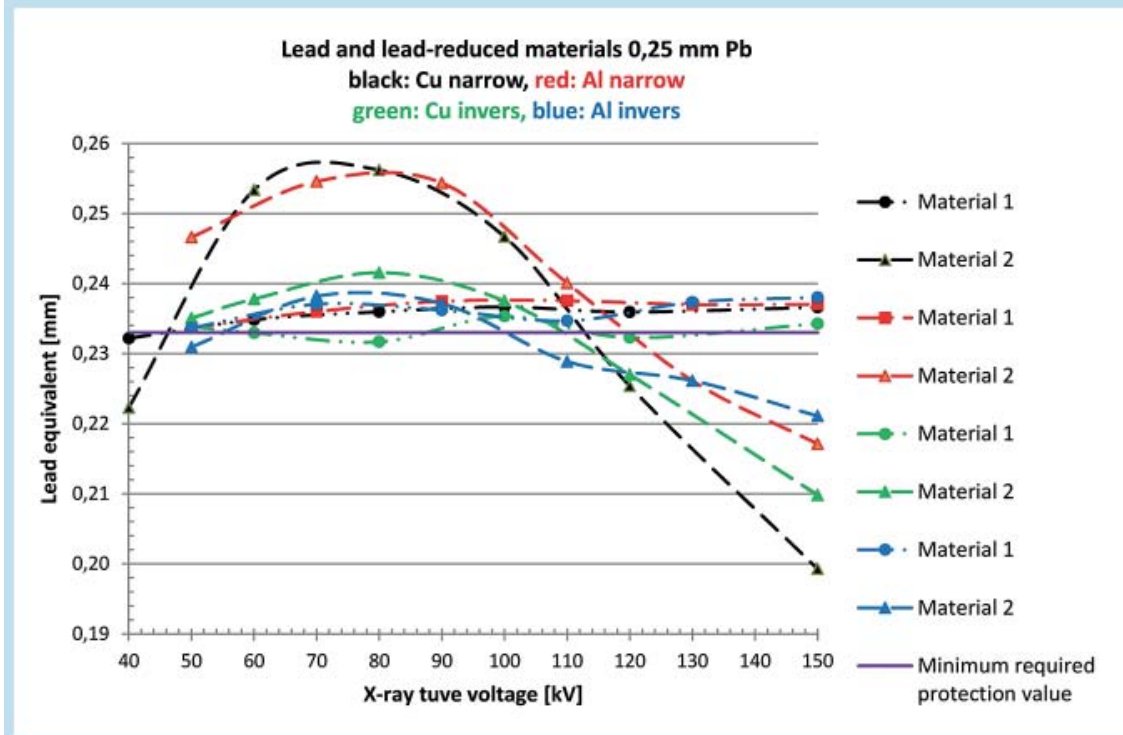

Fig. 4 Lead equivalents of $0.25 \mathrm{~mm} \mathrm{~Pb}$ - materials for all four methods of measurement for lead (material 1) and a lead-reduced material.

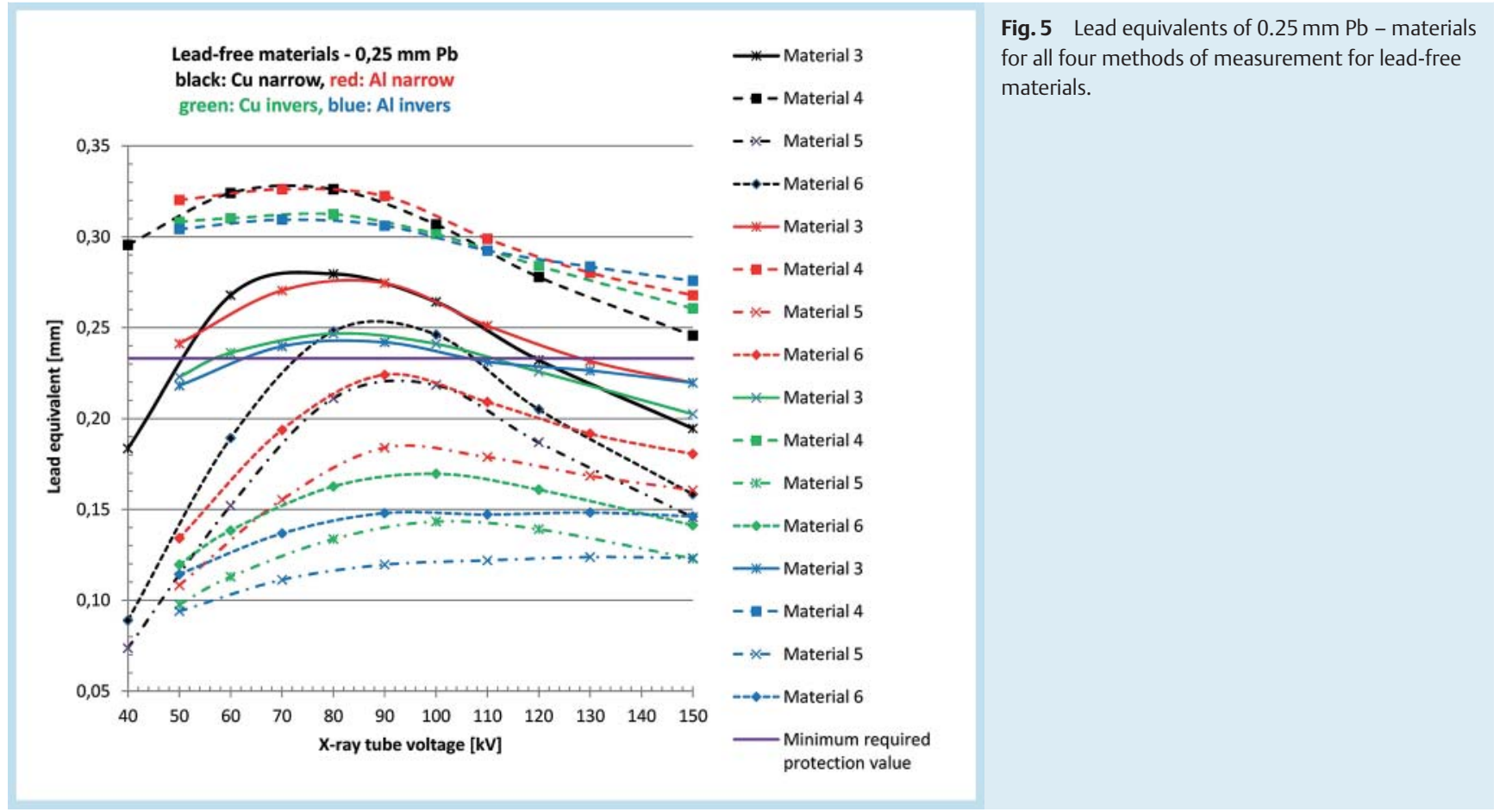

The minimum value for the lead equivalent of a radiation protection apron is defined differently in the individual standards.

DIN 6857-1 specifies a maximum permissible lower deviation of $7 \%$. Given a target value of $0.25 \mathrm{~mm} \mathrm{~Pb}$, a lead equivalent of at least $0.233 \mathrm{~Pb}$ must be achieved. In addition, this lead equivalent must be maintained in an X-ray tube voltage range of $50 \mathrm{kV}$ to $120 \mathrm{kV}$.

This is not defined in EN 61331-1. It is only noted in a footnote regarding national standard DIN EN 61331-3 [10] that the nominal lead equivalents must not fall below the limit by more than $10 \%$. However, it is sufficient here to maintain this tolerance at one X-ray tube voltage, for example $100 \mathrm{kV}$. A lower deviation of minus $7 \%$ is also permissible in the new standard IEC 61331-1 (2014). According to this stand- ard, the product description of radiation protection clothing must state the voltage range of this permissible deviation. Inverse broad beam geometry is stated as the measurement method of choice in IEC 61331-1 (2014).

Some of the lead equivalents of the measured samples are significantly below as well as above the permissible lower deviations.

To be able to compare all measurement methods with one another, a standard deviation of $7 \%$ was selected.

If attenuation factor $\mathrm{F}$ at one $\mathrm{X}$-ray tube voltage is greater than 250 , the protection provided by the radiation protection apron is sufficient according to DIN 6857-1 and IEC 61331-1 (2014) for this radiation quality regardless of the measured lead equivalent. This basic condition was uni- 


\begin{tabular}{|c|c|c|c|c|c|}
\hline \multicolumn{2}{|l|}{ method of measurement } & \multicolumn{2}{|l|}{ cu-narrow } & \multicolumn{2}{|l|}{ cu-inverse } \\
\hline test sample & $\begin{array}{l}\text { actual } \\
\text { mass [kg] }\end{array}$ & $\begin{array}{l}\text { required } \\
\text { mass [kg] }\end{array}$ & $\begin{array}{l}\text { comparison } \\
\text { to material } 1\end{array}$ & $\begin{array}{l}\text { required } \\
\text { mass [kg] }\end{array}$ & $\begin{array}{l}\text { comparison } \\
\text { to material } 1\end{array}$ \\
\hline material $1(0.25 \mathrm{~mm} \mathrm{~Pb})$ & 2.70 & 2.68 & $100 \%$ & 2.71 & $100 \%$ \\
\hline material $1(0.35 \mathrm{~mm} \mathrm{~Pb})$ & 3.79 & 3.75 & $100 \%$ & 3.79 & $100 \%$ \\
\hline material $1(0.5 \mathrm{~mm} \mathrm{~Pb})$ & 5.42 & 5.35 & $100 \%$ & 5.42 & $100 \%$ \\
\hline material 2 (0.25 mm Pb) & 2.45 & 2.86 & $107 \%$ & 2.72 & $100 \%$ \\
\hline material $2(0.35 \mathrm{~mm} \mathrm{~Pb})$ & 3.27 & 3.96 & $106 \%$ & 3.73 & $98 \%$ \\
\hline material $2(0.5 \mathrm{~mm} \mathrm{~Pb})$ & 4.89 & 5.78 & $108 \%$ & 5.45 & $101 \%$ \\
\hline material $3(0.25 \mathrm{~mm} \mathrm{~Pb})$ & 2.53 & 3.03 & $113 \%$ & 2.91 & $107 \%$ \\
\hline material $3(0.35 \mathrm{~mm} \mathrm{~Pb})$ & 3.50 & 4.33 & $116 \%$ & 4.08 & $108 \%$ \\
\hline material $3(0.5 \mathrm{~mm} \mathrm{~Pb})$ & 4.43 & 6.25 & $117 \%$ & 5.79 & $107 \%$ \\
\hline material $4(0.25 \mathrm{~mm} \mathrm{~Pb})$ & 3.10 & 2.94 & $110 \%$ & 2.77 & $102 \%$ \\
\hline material 4 (0.35 mm Pb) & 3.98 & 4.10 & $110 \%$ & 3.88 & $102 \%$ \\
\hline material 4 (0.5 mm Pb) & 6.10 & 5.93 & $111 \%$ & 5.61 & $103 \%$ \\
\hline material $5(0.25 \mathrm{~mm} \mathrm{~Pb})$ & 2.16 & 6.81 & $255 \%$ & 5.14 & $190 \%$ \\
\hline material $6(0.25 \mathrm{~mm} \mathrm{~Pb})$ & 2.25 & 5.88 & $220 \%$ & 4.37 & $161 \%$ \\
\hline material 7 (0.35 mm Pb) & 3.20 & 4.17 & $111 \%$ & 4.43 & $117 \%$ \\
\hline material 8 (0.35 mm pb) & 3.49 & 4.62 & $123 \%$ & 4.17 & $110 \%$ \\
\hline material $9(0.35 \mathrm{~mm} \mathrm{~Pb})$ & 2.84 & 3.70 & $99 \%$ & 3.80 & $100 \%$ \\
\hline material $10(0.5 \mathrm{~mm} \mathrm{~Pb})$ & 4.27 & 5.87 & $110 \%$ & 5.57 & $103 \%$ \\
\hline
\end{tabular}

Table 3 Required masses of front aprons for different materials compared to a lead apron (material 1) in the methods of measurement with Cu filtration in an Xray tube voltage range up to and including $150 \mathrm{kV}$.

\begin{tabular}{|c|c|c|c|c|c|}
\hline \multicolumn{2}{|l|}{ method of measurement } & \multicolumn{2}{|l|}{ al-narrow } & \multicolumn{2}{|l|}{ al-inverse } \\
\hline test sample & $\begin{array}{l}\text { actual } \\
\text { mass [kg] }\end{array}$ & $\begin{array}{l}\text { required } \\
\text { mass [kg] }\end{array}$ & $\begin{array}{l}\text { comparison } \\
\text { to material } 1\end{array}$ & $\begin{array}{l}\text { required } \\
\text { mass }[\mathrm{kg}]\end{array}$ & $\begin{array}{l}\text { comparison } \\
\text { to material } 1\end{array}$ \\
\hline material 1 (0.25 mm Pb) & 2.70 & 2.69 & $100 \%$ & 2.69 & $100 \%$ \\
\hline material 1 (0.35 mm Pb) & 3.79 & 3.77 & $100 \%$ & 3.76 & $100 \%$ \\
\hline material 1 (0.5 mm Pb) & 5.42 & 5.38 & $100 \%$ & 5.37 & $100 \%$ \\
\hline material 2 (0.25 mm Pb) & 2.45 & 2.62 & $98 \%$ & 2.58 & $96 \%$ \\
\hline material 2 (0.35 mm Pb) & 3.27 & 3.66 & $97 \%$ & 3.57 & $95 \%$ \\
\hline material 2 (0.5 mm Pb) & 4.89 & 5.40 & $100 \%$ & 5.22 & $97 \%$ \\
\hline material 3 (0.25 mm Pb) & 2.53 & 2.68 & $100 \%$ & 2.70 & $101 \%$ \\
\hline material 3 (0.35 mm Pb) & 3.50 & 3.88 & $103 \%$ & 3.76 & $100 \%$ \\
\hline material 3 (0.5 mm Pb) & 4.43 & 5.63 & $105 \%$ & 5.41 & $101 \%$ \\
\hline material 4 (0.25 mm Pb) & 3.10 & 2.69 & $100 \%$ & 2.62 & $97 \%$ \\
\hline material 4 (0.35 mm Pb) & 3.98 & 3.81 & $101 \%$ & 3.67 & $97 \%$ \\
\hline material 4 (0.5 mm Pb) & 6.10 & 5.55 & $103 \%$ & 5.36 & $100 \%$ \\
\hline material 5 (0.25 mm Pb) & 2.16 & 4.64 & $172 \%$ & 5.35 & $199 \%$ \\
\hline material 6 (0.25 mm Pb) & 2.25 & 3.90 & $145 \%$ & 4.57 & $170 \%$ \\
\hline material 7 (0.35 mm Pb) & 3.20 & 4.14 & $110 \%$ & 4.57 & $121 \%$ \\
\hline material 8 (0.35 mm Pb) & 3.49 & 4.16 & $110 \%$ & 4.13 & $110 \%$ \\
\hline material 9 (0.35 mm Pb) & 2.84 & 3.69 & $98 \%$ & 3.91 & $104 \%$ \\
\hline material 10 (0.5 mm Pb) & 4.27 & 5.49 & $102 \%$ & 5.33 & $99 \%$ \\
\hline
\end{tabular}

Table 4 Required masses of front aprons for different materials compared to a lead apron (material 1) in the methods of measurement with Al filtration in an Xray tube voltage range up to and including $150 \mathrm{kV}$. formly used for all measurement methods in the following evaluations.

The lead equivalent calculated from the attenuation factor has in good approximation a linear relationship with the mass per unit area $\mathrm{m}_{\mathrm{F}}$. The masses per unit area were calculated from the ratio of mass $\mathrm{m}$ to area $\mathrm{A}$ of the individual samples.

$\mathrm{m}_{\mathrm{F}}=\frac{\mathrm{m}}{\mathrm{A}}$

The required mass per unit area $m_{F}$ for the lower limit value of the lead equivalent was calculated via a linear interpolation for every measurement method for every measured $\mathrm{X}$-ray tube voltage.

There is one mass per unit area that generates the same attenuation factor as the corresponding lead at every voltage for each material. The maximum of these masses per unit area in the considered measurement method is the required mass per unit area of this material for the targeted lead equivalent.

The mass of a radiation protection apron is calculated from the mass per unit area of the material multiplied by the area of the protective material.

Thus the masses of radiation protection aprons can be calculated using the required masses per area unit and compared to one another.

\section{Results}

The lead equivalents of the radiation protection materials are specified with a nominal value of $0.25 \mathrm{~mm} \mathrm{~Pb}$ in - Fig. 4, 5. The dependence of the lead equivalents on radia- 


\begin{tabular}{|c|c|c|c|c|c|}
\hline \multicolumn{2}{|l|}{ method of measurement } & \multicolumn{2}{|l|}{ cu-narrow } & \multicolumn{2}{|l|}{ cu-inverse } \\
\hline test sample & $\begin{array}{l}\text { actual } \\
\text { mass [kg] }\end{array}$ & $\begin{array}{l}\text { required } \\
\text { mass }[\mathrm{kg}]\end{array}$ & $\begin{array}{l}\text { comparison } \\
\text { to material } 1\end{array}$ & $\begin{array}{l}\text { required mass } \\
{[\mathrm{kg}]}\end{array}$ & $\begin{array}{l}\text { comparison } \\
\text { to material } 1\end{array}$ \\
\hline material 1 (0.25 mm Pb) & 2.70 & 2.68 & $100 \%$ & 2.71 & $100 \%$ \\
\hline material $1(0.35 \mathrm{~mm} \mathrm{~Pb})$ & 3.79 & 3.75 & $100 \%$ & 3.79 & $100 \%$ \\
\hline material $1(0.5 \mathrm{~mm} \mathrm{~Pb})$ & 5.42 & 5.35 & $100 \%$ & 5.42 & $100 \%$ \\
\hline material $2(0.25 \mathrm{~mm} \mathrm{~Pb})$ & 2.45 & 2.45 & $92 \%$ & 2.42 & $89 \%$ \\
\hline material 2 (0.35 mm Pb) & 3.27 & 3.27 & $87 \%$ & 3.25 & $86 \%$ \\
\hline material $2(0.5 \mathrm{~mm} \mathrm{~Pb})$ & 4.89 & 4.64 & $87 \%$ & 4.60 & $85 \%$ \\
\hline material 3 (0.25 mm Pb) & 2.53 & 2.53 & $95 \%$ & 2.64 & $98 \%$ \\
\hline material $3(0.35$ mm Pb) & 3.50 & 3.50 & $94 \%$ & 3.38 & $89 \%$ \\
\hline material $3(0.5 \mathrm{~mm} \mathrm{~Pb})$ & 4.43 & 4.44 & $83 \%$ & 4.59 & $85 \%$ \\
\hline material 4 (0.25 mm Pb) & 3.10 & 2.44 & $91 \%$ & 2.39 & $88 \%$ \\
\hline material 4 (0.35 mm Pb) & 3.98 & 3.27 & $87 \%$ & 3.30 & $87 \%$ \\
\hline material $4(0.5 \mathrm{~mm} \mathrm{~Pb})$ & 6.10 & 4.99 & $93 \%$ & 4.63 & $85 \%$ \\
\hline material 5 (0.25 mm Pb) & 2.16 & 6.81 & $255 \%$ & 5.14 & $190 \%$ \\
\hline material 6 (0.25 mm Pb) & 2.25 & 5.88 & $220 \%$ & 4.37 & $161 \%$ \\
\hline material 7 (0.35 mm Pb) & 3.20 & 3.43 & $92 \%$ & 4.43 & $117 \%$ \\
\hline material 8 (0.35 mm Pb) & 3.49 & 3.49 & $93 \%$ & 4.00 & $106 \%$ \\
\hline material $9(0.35 \mathrm{~mm} \mathrm{~Pb})$ & 2.84 & 3.25 & $87 \%$ & 3.80 & $100 \%$ \\
\hline material 10 (0.5 mm Pb) & 4.27 & 4.72 & $88 \%$ & 4.80 & $88 \%$ \\
\hline
\end{tabular}

Table 5 Required masses of front aprons for different materials compared to a lead apron (material 1) in the methods of measurement with Cu filtration in an Xray tube voltage range up to and including $100 \mathrm{kV}$.

\begin{tabular}{|c|c|c|c|c|c|}
\hline \multicolumn{2}{|l|}{ method of measurement } & \multicolumn{2}{|l|}{ al-narrow } & \multicolumn{2}{|l|}{ al-inverse } \\
\hline test sample & $\begin{array}{l}\text { actual } \\
\text { mass [kg] }\end{array}$ & $\begin{array}{l}\text { required } \\
\text { mass [kg] }\end{array}$ & $\begin{array}{l}\text { comparison } \\
\text { to material } 1\end{array}$ & $\begin{array}{l}\text { required } \\
\text { mass }[\mathrm{kg}]\end{array}$ & $\begin{array}{l}\text { comparison } \\
\text { to material } 1\end{array}$ \\
\hline material 1 (0.25 mm Pb) & 2.70 & 2.69 & $100 \%$ & 2.69 & $100 \%$ \\
\hline material 1 (0.35 mm Pb) & 3.79 & 3.77 & $100 \%$ & 3.76 & $100 \%$ \\
\hline material 1 (0.5 mm Pb) & 5.42 & 5.38 & $100 \%$ & 5.37 & $100 \%$ \\
\hline material 2 (0.25 mm Pb) & 2.45 & 2.31 & $86 \%$ & 2.47 & $92 \%$ \\
\hline material 2 (0.35 mm Pb) & 3.27 & 3.17 & $84 \%$ & 3.29 & $87 \%$ \\
\hline material 2 (0.5 mm Pb) & 4.89 & 4.55 & $85 \%$ & 4.65 & $87 \%$ \\
\hline material 3 (0.25 mm Pb) & 2.53 & 2.44 & $91 \%$ & 2.70 & $100 \%$ \\
\hline material 3 (0.35 mm Pb) & 3.50 & 3.19 & $85 \%$ & 3.44 & $91 \%$ \\
\hline material 3 (0.5 mm Pb) & 4.43 & 4.40 & $82 \%$ & 4.61 & $86 \%$ \\
\hline material 4 (0.25 mm Pb) & 3.10 & 2.32 & $86 \%$ & 2.41 & $90 \%$ \\
\hline material 4 (0.35 mm Pb) & 3.98 & 3.22 & $85 \%$ & 3.30 & $88 \%$ \\
\hline material 4 (0.5 mm Pb) & 6.10 & 4.57 & $85 \%$ & 4.64 & $86 \%$ \\
\hline material 5 (0.25 mm Pb) & 2.16 & 4.64 & $172 \%$ & 5.35 & $199 \%$ \\
\hline material 6 (0.25 mm Pb) & 2.25 & 3.90 & $145 \%$ & 4.57 & $170 \%$ \\
\hline material 7 (0.35 mm Pb) & 3.20 & 4.14 & $110 \%$ & 4.57 & $121 \%$ \\
\hline material 8 (0.35 mm Pb) & 3.49 & 3.49 & $93 \%$ & 4.13 & $110 \%$ \\
\hline material 9 (0.35 mm Pb) & 2.84 & 3.69 & $98 \%$ & 3.91 & $104 \%$ \\
\hline material 10 (0.5 mm Pb) & 4.27 & 4.71 & $88 \%$ & 4.83 & $90 \%$ \\
\hline
\end{tabular}

Table 6 Required masses of front aprons for different materials compared to a lead apron (material 1) in the methods of measurement with Al filtration in an Xray tube voltage range up to and including $100 \mathrm{kV}$. tion quality for the nominal values of $0.35 \mathrm{~mm} \mathrm{~Pb}$ and $0.5 \mathrm{~mm} \mathrm{~Pb}$ is very similar and was not separately shown. For radiation protection materials with a nominal value of $0.25 \mathrm{~mm} \mathrm{~Pb}$, the attenuation factors were listed in $\bullet$ Fig. 6 for the lead material (material 1 ), the lead-reduced material (material 2), and the lead-free material (material 6). These three materials were selected as examples to show the major differences in attenuation factors. Only the attenuation factors for the inverse geometry with $\mathrm{Al}$ filtration were specified in - Fig. 6 since this method is to be applied in accordance with IEC 61331-1 (2014) to categorize radiation protection materials in the usual protection classes of $0.25 \mathrm{~mm} \mathrm{~Pb}, 0.35 \mathrm{~mm} \mathrm{~Pb}$, and $0.5 \mathrm{~mm} \mathrm{~Pb}$. These attenuation factors are most comparable with those that would result in the case of the attenuation of scattered radiation from the patient.
The required masses were calculated for a front apron as an example. The necessary area is approx. $0.8 \mathrm{~m}^{2}$ of the protection material here.

The results of these calculations are listed in o Table 3-6. - Table 3, 4 show the calculated required masses of radiation protection aprons for the different materials using all four measurement methods in an X-ray tube voltage range up to and including $150 \mathrm{kV}$. The mass values for a lead apron are listed at the top of the tables.

The percentage of the required mass of a radiation protection apron compared to the required mass for the minimally required lead equivalent of $0.233 \mathrm{~mm} \mathrm{~Pb}$ of the lead apron (material 1) is listed in the column next to the required masses. Values greater than $100 \%$ mean that the mass of the radiation protection apron is greater than a lead apron. 


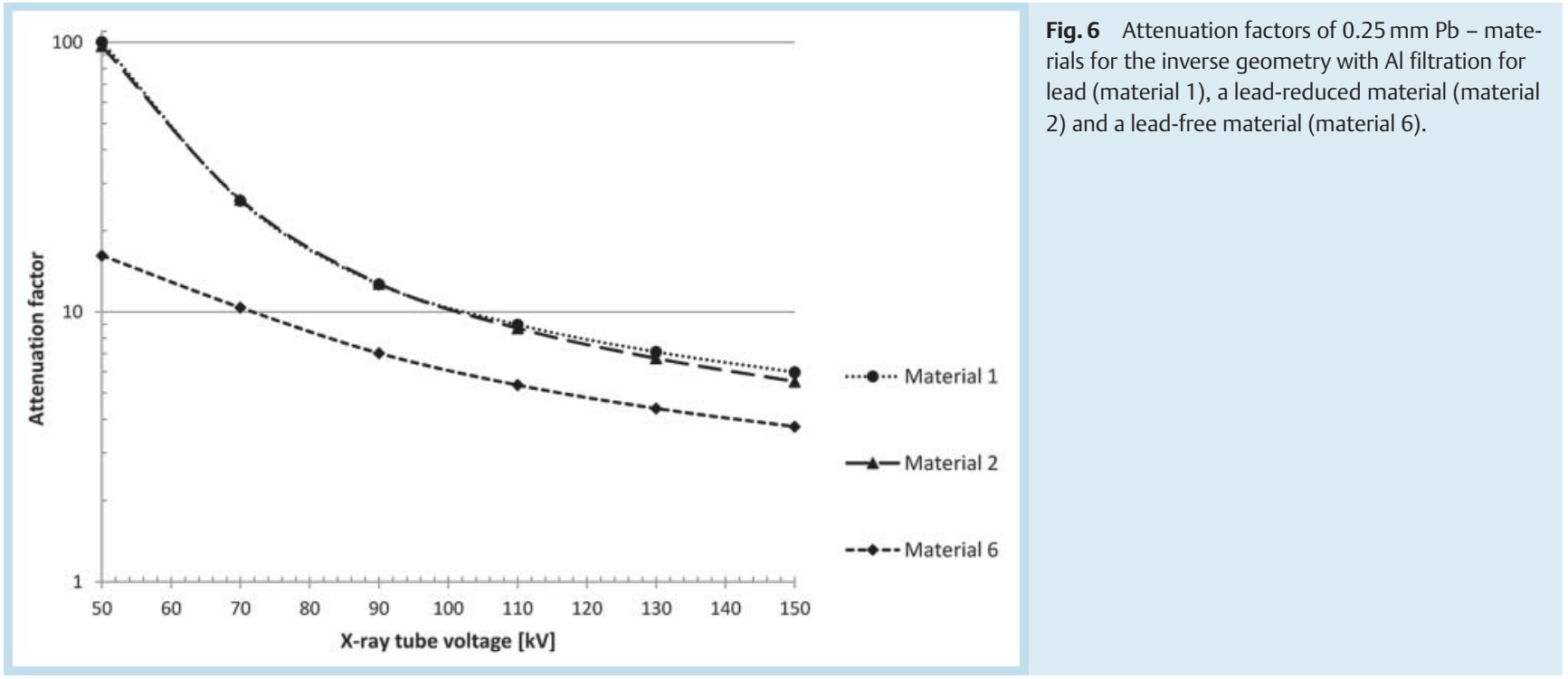

- Table 5, 6 show the required masses in an X-ray tube voltage range up to and including $100 \mathrm{kV}$. For measurements with Al filtration according to IEC 61331-1, the values for $100 \mathrm{kV}$ were calculated via interpolation.

\section{Discussion}

$\nabla$

Comparison of measurement methods

- Fig. 4, 5 show that the calculated lead equivalent of the samples depends on the radiation quality and the measurement method. The studies by Eder et al. and Pichler et al. also show similar results

For almost all samples, the measurements in the narrow beam show a higher lead equivalent compared to the methods in inverse geometry at X-ray tube voltages of up to approx. $110 \mathrm{kV}$. This effect is significantly more pronounced in the case of lead-free materials. A significant difference between the results of the measurement methods with $\mathrm{Cu}$ filtration and $\mathrm{Al}$ filtration was seen in some samples (e. g. material 6). The inverse geometry measurements with $\mathrm{Al}$ filtration show the lowest lead equivalent in the X-ray tube voltage range of up to approx. $110 \mathrm{kV}$.

However, in the case of X-ray tube voltages above approximately $110 \mathrm{kV}$, the lead equivalent in the narrow beam can be lower than in inverse geometry depending on the material (refer to materials 2, 3, and 4).

Material 6 achieves the minimum required protection value only in the measurement method in the narrow beam with $\mathrm{Cu}$ filtration in an X-ray tube voltage range of $80 \mathrm{kV}$ to $100 \mathrm{kV}$. This value is not achieved in the case of material 5. These results can be explained by the fact that the absorption coefficient of lead increases dramatically above the K-absorption edge at $88 \mathrm{keV}$. The absorption coefficient is always lower in the case of lead-free materials and lead-reduced materials, which have a lower lead content, compared to a pure lead material starting at an X-ray tube voltage of $88 \mathrm{kV}$. This effect is always more pronounced at higher X-ray tube voltages since an increasingly greater proportion of the $\mathrm{X}$ ray spectrum has energies above $88 \mathrm{keV}$.
Due to the lower hardening of the X-ray spectra, the attenuation factors are higher in measurement methods with $\mathrm{Al}$ filtration than those with $\mathrm{Cu}$ filtration. An attenuation factor of 250 is not achieved for the materials shown in - Fig. 6.

\section{Comparison of the required masses}

A comparison of the required masses of the radiation protection aprons to a pure lead apron shows that the use of lead-free or lead-reduced materials allows a maximum mass reduction of $5 \%$ with the measurement method of inverse geometry with Al filtration in the entire X-ray tube voltage range to $150 \mathrm{kV}$ (refer to material 2 in 0 Table 4).

Higher masses of the radiation protection aprons are required in some cases for the other materials. If the dependence of the lead equivalent on the X-ray tube voltage is very pronounced, e. g. in the case of material 6 , the required mass for achieving the minimum required protection value can be more than double the actual mass of the lead apron in the extreme case.

However, X-ray tube voltages above $100 \mathrm{kV}$ are rarely used in surgery and in angiography. If the rated range of the aprons is limited to X-ray tube voltages of up to $100 \mathrm{kV}$, a mass reduction of up to $18 \%$ for material 3 compared to a lead apron is possible. The possible mass reduction is lower for the other materials or a higher mass is necessary for some materials even at X-ray tube voltages of up to $100 \mathrm{kV}$. The measurement method plays a major role for some materials in these comparisons. Therefore, the possible mass reduction is $8 \%$ for material 7 in the measurement method in the narrow beam with copper filtration according to DINEN 61331-1 (2002). According to the new standard IEC 61331-1 (2014), the apron would have to be $21 \%$ heavier to meet the standard requirements for up to $100 \mathrm{kV}$ in inverse geometry with aluminum filtration.

The possible mass reduction for the same materials depends not only on the measurement method and X-ray tube voltage range but also on the nominal lead equivalent (e.g. material 3).

Materials are currently being tested in the USA according to the standard ASTM F2547 [11]. This standard corresponds 
largely to the requirements of IEC 61331-1 (2014) for the narrow beam. The radiation qualities are specified in halfvalue layers in standard ASTM F2547. Given an X-ray tube with a $\mathrm{W}$-anode and an anode angle of $17^{\circ}$, the required aluminum filtration is $4.7 \mathrm{~mm} \mathrm{Al}$ at an X-ray tube voltage of $60 \mathrm{kV}$ and approx. $6.2 \mathrm{~mm} \mathrm{Al}$ at an X-ray tube voltage of $130 \mathrm{kV}$.

However, compared to the new preferred method of inverse geometry according to IEC 61331-1 (2014), there are significant differences here depending on the material composition of the radiation protection clothing since the lead equivalent is determined in the narrow beam and at a different radiation quality according to ASTM F2547.

Another problem with inverse geometry is the incomplete irradiation of the measurement chamber for the air kerma behind the radiation protection material. All measurement chambers that meet the requirements of IEC 61331-1 (2014) regarding energy dependence and repeat accuracy have always been tested for complete homogeneous irradiation of the entire measurement chamber in type testing. However, the chamber is only partially irradiated in inverse geometry ( $\bullet$ Fig. 2). It is not yet known whether this will yield comparable results when using different measurement chambers in different testing devices.

For users of radiation protection aprons, not only sufficient protection but also the lowest possible mass is advantageous since radiation protection clothing often has to be worn for numerous hours a day. A maximum tolerance of minus $7 \%$ for the nominal lead equivalent in the total X-ray tube voltage range of radiodiagnostics significantly limits the possibilities for reducing the mass of lead-free and lead-reduced radiation protection materials compared to pure lead materials. Clear classification of radiation protection materials up to an X-ray tube voltage of $100 \mathrm{kV}$, for example, offers a bit of flexibility for lighter radiation protection materials.

\section{Conclusion}

$\checkmark$

Definition of a uniform testing standard seems necessary for both manufacturers and users of radiation protection materials for the following reasons:

- Manufacturers can develop products that can be sold internationally.

- Users can trust that the radiation protection materials have been tested accordingly.
It is not yet known whether the new testing standard IEC 61331-1 (2014) will be able to become established as an internationally recognized testing standard.

\section{Clinical relevance of the study}

- The attenuation factor and lead equivalent are highly dependent on the measurement method.

- The X-ray spectra used in the different measurement methods can only be conditionally compared to the spectra of scattered radiation from the patient.

- A reduction of the mass of radiation protection clothing is only possible for a limited range of use.

\section{References}

1 EN. Strahlenschutz in der medizinischen Röntgendiagnostik - Teil 1: Bestimmung von Schwächungseigenschaften von Materialien (IEC 61331-1:1994). Berlin: Beuth; 2002, EN 61331-1

2 Eder H, Panzer W, Schöfer $H$. Ist der Bleigleichwert zur Beurteilung der Schutzwirkung bleifreier Röntgenschutzkleidung geeignet? Fortschr Röntgenstr 2005; 177: 399-404

3 Schlattl H, Zankl M, Eder H et al. Shielding properties of lead-free protective clothing and their impact on radiation doses. Med Phys 2007; 34: $4270-4280$

4 McCaffrey JP, Tessier F, Shen $H$. Radiation shielding materials and radiation scatter effects for interventional radiology (IR) physicians. Med Phys 2012; 39: 4537-4546

5 DIN. Strahlenschutzzubehör bei medizinischer Anwendung von Röntgenstrahlung - Teil 1: Bestimmung der Abschirmeigenschaften von bleifreier oder bleireduzierter Schutzkleidung. Berlin: Beuth; 2009, DIN 6857-1

6 Pichler T, Schöpf T, Ennemoser O. Strahlenschutzkleidung in der Röntgendiagnostik - Vergleich der Schwächungsgleichwerte im schmalen Strahlenbündel und in inverser Breitstrahlgeometrie. Fortschr Röntgenstr 2011; 183: 470-476

7 IEC. Protective devices against diagnostic medical X-radiation - Part 1: Determination of attenuation properties of materials. Geneva: IEC 2014 IEC 61331-1, Ed. 2

8 Poludniowski G, Landry G, DeBlois F et al. SpekCalc: a program to calculate photon spectra from tungsten anode X-ray tubes. Phys Med Biol 2009; 54: N433-N438

9 Fehrenbacher G, Panzer W, Tesfu K. Spectra of diagnostic X-ray scattered by a water phantom, GSF Forschungszentrum; 1996, GSF-Bericht 9/96

10 DIN. Strahlenschutz in der medizinischen Röntgendiagnostik - Teil 3: Schutzkleidung und Gonadenschutz (IEC 61331-3:1998). Berlin: Beuth; 2002, DIN EN 61331-3

11 ASTM F2547 Standard Test Method for Determining the Attenuation Properties in a Primary X-ray Beam of Materials Used to Protect Against Radiation Generated During the Use of X-ray Equipment. (062013) 